Portland State University

PDXScholar

6-17-2018

\title{
European Union Defense Integration: The Quixotic Legacy of the Early Treaties
}

Amanda von Trapp

Portland State University, vontrapp@pdx.edu

Follow this and additional works at: https://pdxscholar.library.pdx.edu/polisci_honors

Part of the Political Science Commons

Let us know how access to this document benefits you.

\section{Recommended Citation}

von Trapp, Amanda, "European Union Defense Integration: The Quixotic Legacy of the Early Treaties" (2018). Political Science Honors Theses. 1.

https://pdxscholar.library.pdx.edu/polisci_honors/1

This Thesis is brought to you for free and open access. It has been accepted for inclusion in Political Science Honors Theses by an authorized administrator of PDXScholar. Please contact us if we can make this document more accessible: pdxscholar@pdx.edu. 
European Union Defense Integration: The Quixotic Legacy of the Early Treaties

Amanda von Trapp

Political Science Honors Thesis

June 17, 2018 
Special thanks to

Dr. David Kinsella

$\&$

Dr. Birol Yeşilada 


\begin{abstract}
European defense integration is encumbered by historic disagreement over two questions - what integration model should be used to develop a common defense and who should be included? The outcome the European Union's earliest and foremost influential security arrangements of the 1940 s and 1950 s instigated a complex legacy of fault lines and friction. This paper looks at the history of the 1947 Dunkirk Treaty, the 1948 Brussels Treaty, and the failed 1954 European Defense Community to illustrate the emergence of two sets of tensions, Atlanticism versus Europeanism and Supranationalism versus Intergovernmentalism. The tensions between these positions explain Europe's inability to reach consensus and why defense integration is such a contested topic among European Union member states. Despite contemporary events that have the potential to galvanize increased harmony, the EU struggles to transcend the quixotic legacy of European defense integration.
\end{abstract}

Keywords: European Defense Integration, Atlanticism, Europeanism, Supranationalism, Intergovernmentalism, nationalism. 
At the 2017 European Security and Defense Conference in Prague, European Union President Jean-Claude Juncker announced that the protection of Europe can no longer be outsourced. ${ }^{1}$ This sentiment predates contemporary dialog as the EU has long struggled with its defense capacity after establishing a post-WWII security arrangement with the United States. Unsuccessful independent military operations in the 1990s won European defense the epithet of a "worm" by Belgium's Foreign Minister, Mark Eyskens. ${ }^{2}$ Since then, the EU has been preoccupied with transforming that worm into a credible, capable, and integrated force through the European Security and Defense Policy, an apparatus that unites EU members under a common policy with shared objectives. Yet, with twenty-eight separate and compartmentalized national defense markets, security and defense matters remain the most intergovernmental component of the EU, which is why the future of European defense integration lacks consensus. ${ }^{3}$ European leaders have openly called for increasing European military capacity in order to ease dependence on their transatlantic guardian, but unanimity among members is contingent upon transcending historic tensions that are a part of a quixotic legacy left by the EU's earliest defense treaties. This research seeks to demonstrate that the lack of consensus regarding European defense integration is due to two sets of tensions that emerged from the EU's earliest defense treaties in the 1940s and 1950s. Using a historical-political narrative, section I will examine the

\footnotetext{
${ }^{1}$ Speech by President Jean-Claude Juncker at the Defense and Security Conference Prague: In Defense of Europe. (June 2017). ULR: http://europa.eu/rapid/press-release_SPEECH-17-1581_en.htm

2 Whitney, Craig. "War in the Gulf: Europe; Gulf Sighting Shatters Europeans' Fragile Unity." The New York Times. (January 1991) URL: https://www.nytimes.com/1991/01/25/world/war-in-the-gulf-europe-gulf-fighting-shatterseuropeans-fragile-unity.html

${ }^{3}$ Moravcsik, Andrew. "The Future of Europe: Coping with Crisis". Great Decisions: Foreign Policy Association. (2017), 18-19.
} 
three treaties and argue firstly, that the 1947 Dunkirk Treaty linked Great Britain to the European continent and introduced the controversial Atlanticist position. Secondly, the 1948 Brussels Treaty would initiate the dichotomous relationship between Europe's anxiety over US withdrawal and its own ambition to achieve strategic autonomy. Thirdly, the 1954 European Defense Community would set the inescapable precedent of preferred intergovernmentalism in matters of European defense. Section // will examine the two sets of tensions provoked by the treatiesintergovernmentalism versus supranationalism and Atlanticism versus Europeanism. Section III will offer contemporary circumstances to conclude how the tensions left by these legacies forestall consensus and encumber defense integration today.

\section{Why Defense?}

In 1943, two anti-fascist prisoners of war conceptualized a post-war plan for a federal Europe that included a European armed service instead of national armies as an assurance against nationalism and war. ${ }^{4}$ Altiero Spinelli and Ernesto Rossi's logic was that by transferring sovereign troops into a common military, Europe could create a de facto community where rivalry and war were no longer possible. European integration in the aftermath of World War II is often described as an effort to end the prolific conflicts that beset the continent, but Stephanie Anderson reasons that while European integration was fundamentally about security, security integration was not necessarily inevitable. ${ }^{5}$ It was not inevitable because of a dissonance

\footnotetext{
${ }^{4}$ Spinelli, Altiero and Enesto Rossi. Ventotene Manifesto, For a Free and United Europe. A Draft Manifesto. 1944. Section II.

${ }^{5}$ Stephanie Anderson, Crafting EU Security Policy: In Pursuit of a European Identity (London: Lynne Reinner. 2008), 76.
} 
between the removal of nationalism to end war and the preservation of national identities deeply ingrained in European countries. Henry Kissinger argues that the discord deals mostly with histories. He states, “...while powers may appear to outsiders as factors in a security arrangement, they appear domestically as expressions of historical existence. No power will submit to a settlement, however well-balanced and however "secure", which seems totally to deny its vision of itself. ${ }^{\prime 6}$ Regarding this, the root of resistance is about national identity, and in preservation of such, also about sovereignty. The most imaginative effort to create a European army, the 1954 European Defense Community, provides an appropriate example since it was not mechanical problems but national pride and fear over lost sovereignty that caused it to fail. Its creator, Jean Monnet, admitted the idea of a European army was "at best premature". ${ }^{7}$ But even with seventy years of participation that has pushed EU members away from national tendencies towards integration, why does defense integration remain so contested?

Ernest Haas sought to understand why EU members chose to integrate in some areas and not others. He theorized the process of European integration as an inevitable outcome of spillover, a motion of incremental participation in some areas that would lead to integration in others, much like a top-down invisible-hand pushing towards greater integration sector by sector. ${ }^{8}$ Haas's observation of small steps evolving into larger goals is evident in the creation of

\footnotetext{
${ }^{6}$ Kissinger, A. Henry. A World Restored: Castlereagh, Metternich and the Restoration of Peace, 1812-1822 (Boston: Houghton Mifflin Company, 1957), 146; Stephanie Anderson, Crafting EU Security Policy: In Pursuit of a European Identity (London: Lynne Reinner. 2008), 45.

${ }^{7}$ Schwartz, Thomas. The Transnational Partnership: Jean Monnet and Jack McCoy, in Monnet and the Americans, ed. Clifford Hackett (Washington, DC: Jean Monnet Council, 1995), 184-185.

${ }^{8}$ Haas, Ernst B. The Uniting of Europe: Political, Social and Economical Forces, 1950-1957, (London: Stevens, 1958), 1968 preface, xxiv-xxv.
} 
many EU institutions, but if his notion of inevitability is correct, how is it that after circuitous growth and incremental collaboration, the EU is still unable to push towards a common defense? Incrementalism is often critiqued as too linear a process because European integration is a result of mixed impulses in which participation can be quickly abandoned or reversed when it no longer serves the interests of involved parties. ${ }^{9}$ Andrew Moravcsik interprets each critical phase in EU integration as intrinsically responsive to the decisions of national governments who bargain with each other on a case-by-case basis, not because they succumbed to a self-reinforcing process built upon fidelity to prior commitments. ${ }^{10}$ Nowhere is this more apparent than in the legacy of Europe's defense and security cooperation. EU member states lack a unanimous vision for European security because they prefer to cooperate when necessary but jealously guard their sovereign authority to make decisions concerning their national troops. Because of this, the twenty-eight EU member states cannot agree on what integration model European defense integration should adopt and who should be involved in European security. Disagreement over these two questions derive from two sets of tensions-Intergovernmentalism versus Supranationalism and Atlanticism versus Europeanism. Before we examine the tensions, uncovering their evolution in these early treaties provides context and evidence of an inescapably complex legacy that can be found in the EU's three earliest defense treaties in the aftermath of WWII.

\footnotetext{
${ }^{9}$ Nelsen, Brent F., and Alexander C-G. Stubb. The European Union: Readings on the Theory and Practice of European Integration, (Boulder, CO: L. Rienner, 1994), 241.

${ }^{10}$ Moravcsik, Andrew. The Choice for Europe: Social Purpose and State Power from Messina to Maastricht. Cornell Studies in Political Economy. (Ithaca, N.Y.: Cornell University Press, 1998), 7-10.
} 


\section{SECTION I: The Treaties}

\section{The Dunkirk Treaty}

The 1947 Dunkirk Treaty is often neglected in EU defense literature, yet it is significant because it sewed Great Britain to the European continent by giving it a say in European security matters. With Great Britain, so too came the Americans and ultimately, Atlanticism.

In 1945, Great Britain had two choices. It could pursue a "third force" as a balance of power against both the United States and an emerging Soviet Union, or it could strengthen the alliance with the US in order to contain the perceived threat of the Soviet Union. ${ }^{11}$ Britain's postwar strategic position was jeopardized by debt and the inability to defend against new technological developments in military equipment. Thus, bankruptcy and a slipping grasp on its empire necessitated an appeal to the Americans. In 1946, Britain implored America to shoulder their financial and military burden of both Greece and Turkey on the grounds that if abandoned, they, the Mediterranean, and the Near East would be lost to communism. ${ }^{12}$ Along with most of Europe, Britain worried the US would revert to isolationist policies and leave Europe incapable of thwarting a conventional military attack should the USSR emerge as Europe's next threat. If the US did withdraw, the need for close cooperation among west European states would be essential. Hedging against both possibilities, Britain kept a diplomatic line with the Americans but simultaneously introduced the idea of a west European security group.

\footnotetext{
${ }^{11}$ Baylis, John. "Britain and the Dunkirk Treaty: The Origins of NATO." The Journal of Strategic Studies. Vol.5. I.2 (June 1982): p 247.

${ }^{12}$ Satterthwaite, Joseph. C. "The Truman Doctrine: Turkey." The Annals of American Academy of Political and Social Science Vol. 401, No. 1. (1972): 75.
} 
France and Britain both had a stake in managing the dominant post-war question regarding what to do with a defeated Germany. Britain hesitated over excessive peace terms because it sought to avoid the hazard of alienating Germany into the arms of the Soviets. France, however, was unamenable to terms that did not end in subduing Germany. France's dependence on foreign coal put its position on Franco-German reconciliation somewhere between serving its imperial interests and mitigating the fear of another German invasion. France was terrified by the possibility of renewed German aggression and eager to sustain access to its industrial Ruhr and Saar regions now under international control. British policymakers, however, were more anxious about Russia, uncertain about America, and at that particular moment, inclined to lead in organizing west Europe. ${ }^{13}$ Despite their imperial rivalry, in early 1944 the British Post Hostilities Planning Staff saw relations with France as critical in establishing any form of European cooperation that may help in buffering influence from the Soviets and the Americans. British Foreign Minister Ernest Bevin put forth the idea of a Western Security Group in the form of a defense pledge between these former competitors.

Negotiations over the Anglo-French military pact began in 1946. Signatories we expected to collaborate "in measures of mutual assistance in the event of any renewal of German aggression...preventing Germany becoming again a menace to peace."14 Britain regarded reference to the "German menace" as unconstructive rhetoric, especially since Britain sought to avoid conditions similar to the interwar period that had contributed to renewed Germany

\footnotetext{
${ }^{13}$ Reynold, D. Britannia Overruled: British Policy and World Power in the Twentieth Century: London: Longham, 1991. pp. 160-61 as quoted by Danilo Ardia in Twentieth-Century Anglo American Relations.

14 "Treaty of Alliance and Mutual between His Majesty in Respect of the United Kingdom of Great Britain and Northern Ireland and the President of the French Republic." The International Law Quarterly, Vol.1. No.4 (Winter 1947).
} 
hostilities. Nevertheless, Britain would allow France the satisfaction in order to guarantee its signature because the treaty also served in convincing the Americans of European cooperation, a loose condition for their continued involvement in the region. The Americans were wary of Europe's desire for peace and sought to avoid entanglements, thus the notion of European states collaborating promised a more appealing environment for American commitment. In 1946, US Secretary of State James F. Byrnes presented the Byrnes Treaty which offered Europe US assistance in preventing Germany from purchasing arms for the next twenty-five years. This treaty was seen as the first tangible sign that the Americans were willing to stay, and Britain was eager to secure it. John Baylis accounts that because of this, Britain did not want the Dunkirk Treaty to appear too capable of achieving the same ends in fear that the US Senate would declare the Byrnes Treaty unnecessary. ${ }^{15}$ Yet, the Byrnes Treaty was strategically valuable because it sought to include the Soviets in international efforts to solve the German problem. To western Europe, the treaty would ensure American presence. To the Americans, it would serve as a tactic to see if the Soviets were willing to cooperate or had intentions of expanding into the whole of Germany. ${ }^{16}$ While the Byrnes Treaty is often seen as a backstage feature in the origins of the transatlantic relationship, it played a role in compelling Great Britain to push western Europe towards cooperation.

In January 1947, US President Harry Truman appointed George Marshall as Secretary of State and the ideas of the Byrnes Treaty were eclipsed by support for German economic

\footnotetext{
${ }^{15}$ Baylis, "Britain and the Dunkirk Treaty," 244-447

${ }^{16}$ Ardina, Danilo in Hollowell, Jonathan. Twentieth-century Anglo-American Relations, (Basingstoke: Palgrave, 2001), 77.
} 
rehabilitation as a "soft containment" strategy. Without the immediate prospect of US military assistance regarding Germany, on March $4^{\text {th }}, 1947$ the Dunkirk Treaty was signed. The Byrnes Treaty remained in negotiations because all parties were eager keep the Soviets involved. Meanwhile, Ernest Bevin leveraged the idea of expanding the Dunkirk Treaty to include more western states as continued evidence to sustain discussion with the Americans on securing military aid in Europe. In June 1947, Marshall announced the European Recovery Plan as an economic program to steady the political situation in Europe. The Marshall Plan was signed by Truman in April 1948 as an alternative to the Byrnes Treaty, the latter of which was eventually dropped for fear of antagonizing Germany into another pact with the Soviets. ${ }^{17}$

Britain's role in these negotiations explain how Atlanticism entered the dynamic of European security. Britain would not be fully accepted into the European continent until it joined the EU in 1973, but the 1947 Dunkirk Treaty stitched Britain to the fabric of Europe's future through the backdoor via defense. This is significant because Britain was never seen as European. As early as 1923, one of the first conceptualizers of a federal Europe, Richard CoudenhoveKalergi, stated that what Europe would gain in territory and strength, they would lose in cohesion by embracing Great Britain. ${ }^{18}$ Due to their relations during WWII, Britain was "unofficially" charged with keeping the Americans involved in the continent to buffer against potential threats. Michael Fogarty argues Britain was perhaps reluctant to this role like Ajax being thrust onto the

\footnotetext{
${ }^{17}$ Pertinax, By. BYRNES ARMS PACT REPORTED DROPPED. New York Times (1923-Current file), Feb 21, 1948. http://stats.lib.pdx.edu/proxy.php?url=http://search.proquest.com/docview/108310279?accountid=13265

${ }^{18}$ Coudenhove-Kalergi, Richard. "Pan-Europe" as quoted by Salmon, Trevor C., and William Nicoll. Building European Union: A Documentary History and Analysis, (Manchester: Manchester Univ. Press, 1997).
} 
front lines. ${ }^{19}$ But Britain's post-war ambitions speak more favorably to the notion that it saw itself as having a leading role in organizing West Europe. Prime Minister Winston Churchill made it abundantly clear in 1946 that while Britain supported the idea of a federation of European states of sort, he did not consider Britain to be one of them. That did not mean that Britain would forego the opportunity to influence Europe's rehabilitation. Yet, security against Germany was not the primary fuel in Britain's pursuit of a West European security arrangement. Head of Supply and Relief Department of the British Foreign office was recorded saying, "If we want to re-establish our position in Europe...the secret lies not in France, but in Western Germany." ${ }^{20}$ On this the British and the Americans held concert. They both believed that Germany would be a better future ally than France, which is why Fogarty suggests that Great Britain had no long-term interest in a security arrangement but used the Dunkirk Treaty as a short-term solution to avoid a politically unstable France from falling to the communists. ${ }^{21}$ The treaty could also be interpreted as a British ploy to hem in its French imperial rival, yet it was clear that if the US was unwilling to remain in the region, Britain's security would need to be strengthened by the creation of a European security group. ${ }^{22}$ It is also important to note ongoing subplot on behalf of Ernest Bevin who did see a larger picture of European solidarity and conducted negotiations under such auspices, although the outcomes were less than he hoped to see for Europe.

19 Fogarty, Michael P. “Britain and Europe Since 1945.” The Review of Politics, Vol.19, No. 1 (Jan., 1957), 90-105.

20 Greenwood, Sean. "Return to Dunkirk: The Origins of the Anglo-French treaty of March 1947." The Journal of Strategic Studies. Vol.6, No. 4. (December, 1983), 52.

${ }^{21}$ See note Footnote 19.

22 Greenwood, Sean. “Ernest Bevin, France and 'Western Union': August 1945-Frebruary 1946." European History Quarterly. Vol. 14. No. 3. (July 1984), 319. 
By accepting the Marshall offer in 1947, Britain became a champion of strengthening its alliance with the US, a factor that pulled it away from the original notion that its own security was wrapped up in the main continent. ${ }^{23}$ Some argue that the Marshall Plan doomed European security integration from the very beginning since it removed the degree of urgency that usually drives reticent parties to collaborate. The Marshall Plan's economic assistance allowed Britain and France to direct greater attention on managing their crumbling empires rather than emphasizing cooperation. France would even use some of its Marshall funds to fight its colonial war in Indo-China. Nevertheless, Danilo Ardina argues the Dunkirk Treaty is significant because in a phase of post-war uncertainty, the final frame of the European system was initiated. ${ }^{24}$ Drawing a straight line from the Dunkirk Treaty to the European Coal and Steel Community is perhaps too linear, although it is worth noting that the Dunkirk Treaty did include language of cultural and economic cooperation. More simply, Ardina is arguing that the Anglo-French pact was concrete proof Europe had decided to pursue a future of cooperation and Great Britain would undeniably be a part of it. Ultimately, the Anglo-American relationship would initiate the Atlanticist position that would solidify in the years to follow.

\footnotetext{
${ }^{23}$ Zeeman, Bert. "Britain and the Cold War: An Alternative Approach. The Treaty of Dunkirk Example." European History Quarterly. Vol. 16. (1986), 353.

${ }^{24}$ Hollowell, Jonathan. "Twentieth century Anglo-American relations", 72.
} 


\section{The Brussels Treaty}

History of the 1948 Brussels Treaty is largely overshadowed by the North Atlantic Pact that followed hard on its heels in 1949. While the North Atlantic Pact profoundly altered European security, the Brussels Treaty explains the origins of the dichotomous and seemingly irreparable dynamic between Europe's long-standing anxiety over US withdrawal and its own ambition to achieve strategic autonomy. It also explains the origins of the Europeanist position.

Expanding the Dunkirk Treaty was delicate because those involved wanted to avoid western European cooperation appearing as premature rallying against Russia. The Soviets had established political and economic influence over an east European bloc and Ernest Bevin sought to use the Brussels Treaty as a basis to establish a Western Union that would unite willing parties under common values, goals, and security. Disagreement over what this proposed Western Union would actually look like and who should be involved hampered negotiations. Not surprisingly, France insisted the new pact maintain the Dunkirk model of suppressing Germany; France sought to eventually establish a protectorate over German's industrial Saar region and acquire extensive rights over the railways. ${ }^{25}$ The US considered Europe's preoccupation with security against Germany to be outmoded and impractical considering Soviet aggression seemed more threatening. Despite the pragmatic diplomacy Secretary Marshall extended towards Moscow, it was becoming increasingly evident that preventing soviet expansion would be necessary. As early as December 1947, Ernest Bevin, French Foreign Minister Georges Bidault, and George Marshall met to deliberate on a federation that included the Americans, a "western

\footnotetext{
${ }^{25}$ Wells, Sherrill Brown. Jean Monnet: Unconventional Statesman. (Boulder: Lynne Rienner, 2011), 128.
} 
democratic system that would not be a formal alliance, but an understanding backed by power, money and resolute action..." in order to save Western civilization from soviet aggression. ${ }^{26}$ The idea was a step towards a robust transatlantic relationship, but the US was more inclined to support European cooperation than participate in a regional defense scheme. Nevertheless, the US did engage in talks regarding a possible transatlantic security arrangement which would include Canada and if it were ever signed, members of this proposed Brussels Treaty. Major disagreement over who would be involved in this Western Union were causing negotiating parties to forestall progress on signing the Brussels Treaty. The reality is that states were hedging, waiting for the Soviets to show their cards and in February 1948, they did just that.

Czechoslovakia straddled a precarious geopolitical position in 1948. It had strong ties with the Soviet Union, friendly relations with Western powers, and sought to act as a bridge between the East and West, communism and democracy. ${ }^{27}$ With Soviet backing, on February $21^{\text {st }}$ the Communist Party of Czechoslovakia carried out a coup on the Czech government and obtained dominant control. This event confirmed that the USSR was a threat to internal European politics and would similarly attempt to destabilize politics in Italy and France next. This galvanized those negotiating over the Brussels Treaty to finally overcome their different positions. The Brussels Treaty was signed one month later on March 1948 adding Belgium, Luxemburg and the Netherlands to the defense pledge. And so, the Brussels Treaty established the Western Union

\footnotetext{
${ }^{26}$ Insall, Tony and P. Salomon. "The Brussels and North Atlantic Treaties, 1947-1949." Documents on British Policy Overseas. Series I, Vol. 10, (2015), ix-x.

27 Svik, Peter. "The Czechoslovak Factor in Western Alliance Building, 1945-1948." Journal of Cold War Studies.Vol.18, No.1 (Winter 2016), 137.
} 
defense pledge that would undergo many permutations over the decades before eventually becoming the EU's current European Security and Defense Policy.

The coup also galvanized the Americans. After convincing Truman that US participation in European security would indicate support to stop the expansion of communist dictatorship and "stiffen moral in the free countries of Europe", Secretary Marshall informed the British ambassador the US was now "prepared to proceed at once with joint discussions on the establishment of an Atlantic security system." ${ }^{28}$ The North Atlantic Treaty would be signed April 1949 thereby granting Europe the security they sought from US participation. However, it was not infinite, which explains why the Brussels Treaty was not dissolved in light of the protection provided by the Americans.

Article $\mathrm{V}$ of the North Atlantic Treaty declared that an armed attack against any of the signed parties shall be considered an attack against them all. Even with this assurance, Europe continue to keep the six-member Western Union security apparatus as a bulwark against the possibility of US withdrawal. The Brussels Treaty bound signatories for fifty years while the North Atlantic Treaty was binding for ten years after which it could be reviewed; after twenty years a signatory could leave. ${ }^{29}$ The Brussels Treaty's more peremptory language made the North Atlantic Treaty's ambiguous use of "action as it deems necessary" only somewhat reassuring. ${ }^{30}$ The Brussels Pact obligated that if any contracting parties be the object of an attack, the other

\footnotetext{
${ }^{28}$ Svik, "The Czechoslovak Factor in Western Alliance Building," 154-156

${ }^{29}$ Brussels Treaty, Brussels, Belgium 1948, Article X; North Atlantic Treaty, Washington D.C. 4 April 1949, Article XII

30 Warren, Lansing. "West Union Speeds Arms Integration: Britain, France, Benelux Meet to Merge Defense Plans into North Atlantic Accord." The New York Times. Dec. 21, 1950.
} 
parties will afford all the military and other aid and assistance in their power. ${ }^{31}$ Yet, the protection offered by the North Atlantic Treaty reduced the degree of urgency Europe initially felt by creating a Western Union security group. The North Atlantic Pact is important because it inextricably linked Europe to the United States and similar to claims about the Marshall Plan, Seth Jones argues that because of the exponential growth of US presence in the region, European defense cooperation became extraneous; US troops in western Europe increased from 79,495 in 1950 to 356,787 in 1955 . Jones's argument demonstrates that security cooperation through the EU has been inversely correlated with American power in Europe, "the lower the American military presence and commitment to the continent, the greater the incentive for cooperation. ${ }^{32}$ In the long-term, the North Atlantic Treaty removed the realistic motivations Europe would have in establishing a common defense. The Western Union became more of a symbol of Europeanism to counteract the growing US influence over security and defense matters. The two security networks would coexist because of Europe's fundamental anxiety over US withdrawal but also because of Europe's desire to reclaim that idea of a Europe as a "third force". This would ultimately create a seemingly irreparable dynamic between the desire to be independent of US protection but being practically incapable of doing so.

\footnotetext{
${ }^{31}$ Brussels Treaty, Article III.

32 Jones, Seth G. "The European Union and the Security Dilemma." Securities Studies. Vol. 12. No. 3, (2010), 119.
} 


\section{European Defense Community}

The Dunkirk and Brussels Treaty were more conventional regarding defense pledges, but in 1950 Europe was very close to fulfilling Spinelli and Rossi's vision of a single European armed service. The European Defense Community is an example of the possibilities and limitations of European defense integration and is important in the narrative because it set the precedent of preferred intergovernmentalism thereafter.

In April 1949, US Secretary of State Dean Acheson, Ernest Bevin and French Foreign Minister Robert Schuman met to discuss the Occupation Statue of West Germany which intended to solve matters regarding West Germany's sovereignty along with establishing its access to Marshall Plan funds. West Germany had now become a pawn in the larger East-West rivalry and the Americans were willing to advance German rehabilitation efforts without France. The French were eager to preserve authority over German coal and steel sources and knowing US policymakers would support a solid step towards European unity that included West Germany, Jean Monnet concocted the European Coal and Steel Community to serve both interests. If Europe was to avoid another continental war, some form of Franco-German reconciliation was necessary. Jean Monnet wrote, "if only the French could lose their fear of German industrial domination, then the greatest obstacle to a united Europe would be removed." ${ }^{33}$ He believed pooling the coal and steel industries formally used to produce the weapons of war would create a guarantee of peace. Robert Schuman would champion this plan before the French National

\footnotetext{
${ }^{33}$ Monnet, Jean. Memoirs. (New York: Doubleday, 1978), 292-293.
} 
Assembly declaring that the joining of industries would make war "not merely unthinkable, but materially impossible."34

Five days after negotiations for the Schuman Plan began, 90,000 North Korean troops crossed the $38^{\text {th }}$ parallel and invaded their southern counterpart. US troops stationed in South Korea returned fire leading Truman to declared war the following day June $25^{\text {th }}, 1950$. The US and Europe suspected the invasion was instigated by the USSR and believed a Soviet attack on Europe was imminent. With the US now involved in Korea, Europeans were concerned the US would not be able counter a threat in the European theater as well. ${ }^{35}$ To assuage such fears, the US agreed to send additional combat divisions to Europe, establish a unified command structure led by an American Supreme Allied Commander, and to create the unified defense force that NATO is today. In exchange, the US wanted to include German units and asked France to support German rearmament in the name of defense against the Soviets. ${ }^{36}$ This instantly jeopardized the Schuman Plan. France knew that if allowed to rearm, Germany would have little interest or need to join the coal and steel community. ${ }^{37}$ As with the Dunkirk and Brussels treaties, an armed Germany was an intolerable outcome for the French. In an effort to mitigate this possibility,

\footnotetext{
34 The Schuman Declaration-May 9, 1950. URL: https://europa.eu/european-union/about-eu/symbols/europeday/schuman-declaration_en

${ }^{35}$ Wells, “Jean Monnet," 139.

${ }^{36}$ Wells, Samuel F. Jr., "The Korean War: Miscalculation and Alliance Transformation," in The Routledge Handbook of Transatlantic Security. Ed. Basil Germond, Jussi M.Hanhimaki, and Georges-Henri Soutou (London: Routledge, 2010), 17-19.

37 Dwan, R. "Jean Monnet and the European Defense Community, 1950-54." Cold War History. Vol. 1. No. 2, (2001), 141-160.
} 
French Prime Minister René Pleven offered western Europe a plan to distract the Americans and avoid the failure of the Schuman Plan.

The Pleven Plan offered to resuscitate the Western Union created by the Brussels Treaty and mold it into a unified supranational European defense force, a fusion of human and material components under a single authority and budget. To the French National Assembly, he implored a seal of commitment to the coal and steel plan after which the French government would find a solution to German military contribution more agreeable to the type of future Europeans envisioned. Thus, to avoid German rearmament as sought by the Americans, Pleven proposed:

...the creation, for the purposes of common defense, of a European army tied to the political institutions of a united Europe... a European army cannot be created simply placing military units side by side, since in practice, this would merely mask a coalition of the old sort. Tasks that can be tackled only in common must be matched by common institutions. ${ }^{38}$

Apart from the appeal to establish more common institutions, French Ministry of Foreign Affairs representative Alexandre Parodi saw the plan merely as "a measure to gain time and avoid the enormous risks of rearmament in Germany." ${ }^{39}$ Fear that an armed Germany may come back to haunt Europe facilitated unexpected support for the in the Pleven's European Defense Community (EDC).

It is astonishing the EDC gained momentum because not only was Europe recently at peace, but European governments did not even agree over nourishing unity beyond avoiding

\footnotetext{
${ }^{38}$ Journal officiel de la République française. Débats Parlementaires. Assemblée nationale. 10.1950. Paris: Imprimerie nationale. "Déclaration du Gouverneur français René Pleven le 24 Octobre 1950", p. $7118-7119$ as quoted by Maxime Lavire in Debating European Security and Defense Policy: Understanding the Complexities (London: New York: Ruotledge: 2014), 60-61.

39 Gavin, Victor. (2010). "Were the interests really parallel? The United States, Western Europe and the Early European Integration Project." Journal of Transatlantic Studies. Vol. 8. No. 1. Pp. 32-43.
} 
renewed conflict between one another. The prevailing narrative of post-war Europe is that from the ashes of a war-torn continent, a moral consensus to break with the past and create a new European federation emerged. ${ }^{40}$ The bitter lessons of war did generate the moral discourse for a peace-driven Europe, but nationalism and state sovereignty were not so readily abandoned after WWII. As aforementioned, both France and Britain sought to maintain and even resuscitate what was left of their empires. Governments in exile returned with strong perspectives of restoring national pride, and parliaments resurfaced despite their inefficacy contributing to the rise of nationalism in the interwar period. The idea of a Pan-Europa or a European federation even predates the end of WWII. French Foreign minister, Aristide Briand, submitted a plan for a European Union in the 1930 after a successful moment in Franco-German reconciliation known as the Locarno period. Briand's memorandum saw a European federation "built not upon the idea of unity but of union" which it to say European cooperation was desired but not at the cost of sovereignty. ${ }^{41}$ In form, the earliest idea of a European Union was grounded in a more intergovernmental framework, such as voluntary cooperation among states, not the creation of a super-state. In the late 30 s and early 40s, Nazi-Fascists would co-opt the notion of a "Greater Europe" into the elimination of the particularism that came with nations because they saw the state-system as antithetical to a new order. ${ }^{42}$ Therefore, the resurgence of the nation-state system after WWII could be examined as a reaction to the sort of independence, identity, and

\footnotetext{
40 McCormick, John. Understanding the European Union (Bakingstoke: Palgrave, 2011), 9.

41 The Briand Memorandum as quoted by Salmon, Trevor C., and William Nicoll. Building European Union: $A$ Documentary History and Analysis. Manchester: Manchester Univ. Press, 1997.

${ }^{42}$ Laughland, John. The Tainted Source: The Undemocratic Origins of the European Ideas. (London: Warner Books, 1998), 14-19.
} 
self-determination that was threatened under the Fascists. European states had undergone a violent disregard for the clear demarcations of state power which made abdicating it to a single bureaucratic authority less appealing. Also present is a deep misgiving towards the experimenting of elite politicians and technocrats who, as best described by Otto von Bismarck, use the word "Europe" to demand from "other powers what they in their own name dare not request." ${ }^{43}$ This sentiment would underwrite much of the European Union's struggle to unify in matters of defense.

Even though the European Coal and Steel Community passed in 1951, the EDC stayed in negotiations until 1954. While it may have begun as a convenient tactic to prevent America from rearming Germany, to Jean Monnet, creating a supranational structure was a part of the "ever closer union" he sought for Europe. Institutional governance was a trending intellectual exercise of elite politicians and bureaucrats in these moments-the Schuman Plan also had a "High Authority" that surpassed the authority of the state and in 1952, the European Political Community aimed at establishing supranational political unity also failed. Monnet believed in technocratic bodies running politics, especially since the politics of the masses were blamed for causing nationalist trouble. More so, there was an emerging ethos among the Christian Democrat party who were interested in governing in a way where political legitimacy would derive from the people but not be exercised by the people. ${ }^{44}$ This would contribute to the concept of a 'democratic deficit' present in EU institutions and a strong reason why maintaining national

\footnotetext{
${ }^{43}$ Original source of Bismarck's statement has been not been located but quote used from Vernon Bogdanor in NewStateman book review on Jonathan Steinberg in Bismarck: a Life. (Oxford: New York: Oxford University Press: 2011). URL: https://www.newstatesman.com/books/2011/03/bismarck-germany-europe-hitler

${ }^{44}$ Forlenza, Rosario. "The Politics of the Abendland: Christian Democracy and the Idea of Europe after the Second World War." Contemporary European History 26, no. 2 (2017): 261-86. doi:10.1017/S0960777317000091.
} 
armies symbolically acts as preservation of sovereignty. In Monnet's efforts to engineer solidarity through these institutions he underestimated the influence of legislative bodies. National pride and state sovereignty ultimately destroyed the idea of the EDC, and most ironically in the very government that proposed the plan. By 1954, France was forced to surrender 11,000 troops near Dien Bien Phu in an embarrassing defeat in Indo-China that bruised French national pride resulting in a surge of French nationalism. With the combined effort of the French Communist Party and General de Gaulle's Rally of the French People Party, the EDC was rejected by the French National Assembly because they saw it as far too supranational a project that would undermine French autonomy and military might. The European Defense Community left Europe's purview four months later on August 30 1954.

Quickly following the failure of the EDC, conferences in both London and Paris were conducted to finally solve the issue of German rearmament. To the Americans and the British, West Germany joining NATO was the best alternative to the EDC and so in 1955, West Germany was admitted to NATO. Five days later the Warsaw Pact was signed and so began the bipolar order that loomed until the late 1990s. The Paris Agreement furthermore reaffirmed the collective-defense union created under the Dunkirk and Brussels treaties by changing the group from the Western Union to Western European Union (WEU). Yet, it would remain relatively dormant within NATO until the Council of Western European Union and the Maastricht Treaty both in 1992. Despite initial efforts to unite in matters of defense, the legacy of the EDC set the stage of a preferred intergovernmental model in such that European states would reject integration that would deny them their national pride and autonomy. 


\section{SECTION II: The Tensions}

\section{Intergovernmentalism and Supranationalism}

Influenced by the outcome of the EDC, the first prevailing tension that impedes consensus is disagreement over what defense integration model the EU should adopt. The "European project" balances two integration models: intergovernmentalism and supranationalism. Intergovernmentalism is an approach to governing that privileges the role of the state in European cooperation. It is rooted in the realist tradition in which states are the key actors and the political relations between states are channeled primarily through national governments. ${ }^{45}$ Cooperation is voluntary, and decisions are made on a case-by-case basis by gathered heads of state and governments who bargain and compromise in order to reach consensus on mutual matters. States are held to their collective commitments but opting out is commonly allowed. Intergovernmentalism holds security and defense to be a fundamental component of state sovereignty and to abdicate authority over national troops would be surrendering independence as a state. The European Security and Defense Policy (ESDP) currently operates under an intergovernmental model. From 1995 through 2012 the EU established and used the European Rapid Operational Force (EUROFOR) composed of 60,000 troops from four EU states. Due to inefficient outcomes and lack of coordination, EUROFOR was dissolved in 2012 for a more itinerate structure of EU Battlegroups. EU Battlegroups consist of 1,500 troops provided by 12member states that are deployable within 15 days for standalone missions or for the initial phase of larger operations. These Battlegroups operate under a voluntary rotating scheme, called

\footnotetext{
${ }^{45}$ Nugent, Neill. The Government and Politics of the European Union (London: Palgrave Macmillan, 2017), 450.
} 
rosterization, where every six months a new pair of Battlegroups is placed on standby to replace the outgoing Battlegroup. Yf Reykers argues this system provides three challenges. First, getting members to commit troops is difficult because they are already limited in their defense capacity. Second, how the Battlegroup will be composed depends on the particular nation in rotation and what type of resources they have available, i.e., land, naval, air, or even niche capabilities. This limits their autonomy because the Battlegroups on standby have to determine how they will carry on the mission but with different resources and outsourcing to NATO is common. Thirdly, Reykers argues that putting one's troops on the roster is a political commitment but it does not guarantee they agree to be deployed when the time comes, that is, they can refuse to do so. ${ }^{46}$ Despite its complicated architecture and the financial and political asymmetry, Moravcsik argues that it is both imposing and technically acts as a united defense force in certain capacities regarding peacekeeping and humanitarian assistance. ${ }^{47}$ Yet even with these small battlegroups, the intergovernmental model makes European defense capabilities incomplete in the conventional sense and fraught with disparateness. EU member states do not regularly agree over when, where, and under what conditions they should participate in collectively managing crises. The 2003 row over the Iraq invasion exposed that unanimous decisions on foreign policy were not an easy task in crucial times. In fact, disagreement over the Iraq invasion caused additional internal fault lines to emerge over diverging philosophies regarding intervention and non-intervention. Intergovernmentalism is sufficient in supporting the particularisms of statehoods, but in terms

\footnotetext{
${ }^{46}$ Reykers, Yf. (2017) “EU Battlegroups: High costs, no benefits” Contemporary Security Policy, 38:3, 457470, DOI: $10.1080 / 13523260.2017 .1348568$

${ }^{47}$ Moravcsik, "The Future of Europe,"17-19.
} 
of the European project, it is critiqued as reinforcing the notions of "self-interest" over greater cooperation.

Security cooperation is not a novel concept, the Dunkirk and Brussel's treaties say as much, but integration takes cooperation much further in that the intention is to become automatic and irrevocable. ${ }^{48}$ Supranationalism challenges the frontiers of dominant state power and sees a united defense force, a single arsenal and policy, as an inevitable step in the European integration process. In order for Europe to become a global actor, members must pool military resources and act as one homogeneous body under the leadership of EU institutions, not the states. Supranationalism is seen as transcending outdated modes of state realism in the name of efficiency and progress for collective ends. Theoretically, this would look more like a traditional army such as the one proposed by the European Defense Community. Such a model seeks to give Europe the institutional capacity to speak with one cohesive voice, but it is a radical departure from the state-system and requires EU member states to sacrifice something they are historically hesitant to forgo.

The models are as mechanical as they are theoretical. Intergovernmentalism is more grounded in the tenants of the 1648 Westphalian tradition which established the modern state system of exclusive state sovereignty. Supranationalism is more aligned with functionalism, where groups or institutions come together to solve problems, the end goal being the obsolescence of the state-system. Europe has had remarkable success in establishing epistemic networks that handle European security through horizontal integration of niche abilities and

\footnotetext{
${ }^{48}$ Cross, Mai'a Davis. Security Integration in Europe: How Knowledge-based Networks Are Transforming the European Union (Ann Arbor: University of Michigan Press, 2014), 50.
} 
apparatuses, but when it comes to defense, some European states are readier to integrate than others. The root of the disagreement is the degree of compromise between strengthening the efficacy of EU institutions and maintaining sovereignty. That the EDC was both proposed and rejected by France is an especially interesting example of the parallelism of the scenario where creative contributions to new governing models war with concessions that appear to jeopardize certain ideas of survival. Interestingly, Great Britain and France would at times have overlapping, albeit nuanced, outlooks on intergovernmentalism and defense, but they would never reach consensus on the long-term vision of who should be involved in the process.

\section{Atlanticism and Europeanism}

The second prevailing tension is about who should be involved in European security. This is ultimately about the United States and a contest between conflicting geopolitical ideologies. The two original signers of the Dunkirk Treaty would ultimately part ways on this regard, each vigorously representing different camps over the future of Europe's security. Great Britain would be a champion of the controversial Atlanticism, and France would ceaselessly promote the idealistic Europeanism.

Atlanticism is the belief that the transatlantic partnership between the United States and Europe is a special relationship where close economic, political, and defense cooperation allows them to mutually prosper. Atlanticists are committed advocates of defense coordination with the US and seek to reinforce European military cooperation with the North Atlantic Treaty Organization (NATO). They see an independent European military as a challenge to that relationship and an unnecessary duplication of resources, especially since most EU members already belong to NATO. In the aftermath of the Dunkirk Treaty and after a few precarious 
moments in the 1960s, Great Britain would become the biggest supporter of the transatlantic relationship, in part due to its instrumental role in securing American involvement after WWII. The Anglo-American relationship created resentment among European states who already struggled with the British involvement in the European project. However, US involvement in European security emerged as a multifaceted dilemma, because the structure of the transatlantic partnership is almost irrevocably necessary for European safety from a practical lens, but such a reality challenges the European identity.

Europeanists believe that as long as the US is on hand to ensure European security and with it, US influence, there will be a clear limit to the ambition of the European project. ${ }^{49}$ As the history above demonstrates, US participation was necessary for protection in the post-war context, but France became skeptical of American influence. Charles de Gaulle would play an instrumental role in shaping France's position on European defense because he believed a colossal transatlantic relationship under American dependence and leadership would "completely swallow up the European Community." ${ }^{50}$ Europeanists see European cooperation as strictly European and a single European defense can act as a way to achieve strategic autonomy in a larger ambition of becoming a global actor beyond economic leadership. ${ }^{51}$ This is not a new ambition, it derives from the notion that Europe could become a "third force" to counterbalance

\footnotetext{
${ }^{49}$ Howorth, Jolyon. "EU-NATO cooperation: The Key to Europe's security future." European Security. Vol. 26. No. 3. (2017), 456.

${ }^{50}$ De Gualle, Charles. Major Addresses, Statements, and Press Conference of General Charles de Gaulle, May 19, 1958-January 31, 1961 (New York: French Embassy Press and Information Bureau, 1964), 213-19.

${ }^{51}$ Cini, Michelle and Nieves Perez-Solórzano Borragàn. European Union Politics. 5th edition, (New York: Oxford University Press: 2016), 242.
} 
the bipolarity of the Americans and the Soviets in which Europe aspired to offer an alternative option. Unable to balance against the US in the post-WWII climate and in order to guarantee security against the soviets, a transatlantic relationship was the most viable option for Europe. Because of this, the American security umbrella allowed "peace to reign in Western Europe" which contributed to Europe experimenting in new political and economic initiatives. ${ }^{52}$ The first half of the twentieth-century cast a dark shroud on Europe, and the architectures of the European project sought Europe's restoration by virtue of its illustrious past to thereafter project a devotion to liberalism and peace. ${ }^{53}$ This refurbished imaged and the new initiatives allowed Europe to develop remarkable economic status and abundant soft power appeal. And while Europe has done well exporting that image, Europeanists also see their soft power as not enough if they are to compete with other superpowers; they wish to see themselves as a civilian power with teeth..$^{54}$

Europeanism however, depends upon engineering a consciousness of shared political destiny and a common future. Why Europeanism and Atlanticism war with one another is that an aid in establishing solidarity among the many diverse European nations was then and remains today the collective recognition that they are not American. America plays the role of the constitutive "other" in order for Europeans to agree on a shared identity consistent with the goals

\footnotetext{
${ }^{52}$ Marjolin, Robert. "French Officialdom: Main Obstacle in Rome Treaty Negotiations" as quoted by Sherrill Brown Wells in Pioneers of European integration and Peace, 1945-1963: a Brief History with Documents, (Boston: Bedford/St. Martin's: 2007).

${ }^{53}$ Spaak, Paul-Henry. The Continuing Battle: Memoirs of a European, 1936-1966. Boston: Little, Brown, 1971), 238253.

${ }^{54}$ German Parliament, $15^{\text {th }}$ legislative period, Answer of the Schröder administration to the parliamentary inquiry from the representatives, Dr. Freidberg Pfluger, Christian Schmidt (Furth), Ulrich Adam, and other representatives of the CDU/CSU faction, government document number 15/2888.
} 
of the European Union. John McCormick categorizes many of the manifest qualities and philosophical differences: Europe exemplifies a more collective society whereas America retains a penchant for individualism; to America's traditionalism, Europe is secular and post materialistic. ${ }^{55}$ One important distinction pertaining to this research however, is that while America amassed hard power capacity after WWII, Europe developed the image of having a low threshold for the use of force. ${ }^{56}$ This makes its desire for increased military power somewhat perplexing because the EU already has the capacity to handle peacekeeping and humanitarian situations. It is rational that the EU would seek to expand its power, but the puzzle is why it desires conventional military capacity when it portrays itself as a new breed of an international actor, an actor that transcends the traditional power dynamics of dominant hard power capacity in a world where violence in statecraft is increasingly rejected. ${ }^{57}$ Why the EU wants a military despite its success as a soft-power and the reality of an international system in which conflicts are increasingly resolved multilaterally, is one side of the same coin that keeps Europe from having one. Creating a European army can be interpreted as an effort to reclaim the European ambition and solidify European identity that has been stymied by the legacy of these early defense treaties.

\footnotetext{
${ }^{55}$ McCormick, John. Understanding the European Union: A Concise Introduction. (Houndmills: Macmillan: 2005), 41.

${ }^{56}$ Habermas, J. and Derrida, J. (2003), "What Binds Europeans Together: A Plea for a Common Foreign Policy, Beginning in the Core of Europe." Constellations, 10: 291-297. doi:10.1111/1467-8675.00333

${ }^{57}$ McCormick, John. The European Superpower, (Basingstoke: Palgrave Macmillan, 2007), 14.
} 


\section{SECTION: III Contemporary Relevance}

Using the history of the early defense treaties, I have outlined three outcomes from whence the lack of consensus emerged. Firstly, the Dunkirk Treaty sewed Great Britain to the European continent by giving it a say in European security matters and ultimately introduced Atlanticism. Second, the Brussels Treaty initiated the dichotomous and seemingly irreparable relationship between Europe's long-standing anxiety over US withdrawal and its own ambition to achieve strategic autonomy. Thirdly, the European Defense Community set the precedent of preferred intergovernmentalism when it comes to defense integration. Taken holistically, all three intermingle to create the quagmire of European defense integration today. This concluding section will look at three contemporary circumstances jointly in order to amplify the conflicting tensions created by these early treaties.

\section{United Kingdom Referendum}

In June 2016, the United Kingdom decided to leave the European Union. The event sparked conjecture over whether its absence would finally galvanize European military integration. In September, the European Council issued the Bratislava Road Map for stronger defense capacity, and in November, the European Parliament voted in robust favor of a European Defense Union. One year later in June 2017, the European Commission launched the European Defense Fund and the Permanent Structured Cooperation on Security and Defense (PESCO) was signed November 2017 by twenty-five EU members. ${ }^{58}$ Signatories committed to progress defense

\footnotetext{
${ }^{58}$ Howorth, Jolyon. "EU-NATO cooperation." 456.
} 
integration in which they would "join forces...spend together, invest together, buy together, and act together." ${ }^{159}$ The United Kingdom was excluded from all these motions. The subsequent timing of these events is not coincidental. Great Britain was seen as an impediment to achieving European cohesion because of its position on strengthening relations with NATO rather than establishing European strategic autonomy. With the UK's absence, the EU can ostensibly reclaim that seventy-year-long ambition of a European "third force" free from the influence of the transatlantic relationship. Yet, like many of its predecessors, these motions run the risk of being more symbolic than transformative until put into action or whether or not they are done in joint coordination or competition with NATO. Yet, rather than seeing "Brexit" as a grand liberation from the Anglo-American relationship that withheld Europeanism from fulfilling its potential, perhaps this momentary rise in EU defense cooperation can be interpreted as Europe worrying that the UK's absence is a precursor to US withdrawal.

\section{"America First", Fear of US Withdrawal and the Self-fulfilling Prophecy}

In 2017 German Chancellor Angela Merkel proclaimed, "Let's not fool ourselves. From the point of view of some of our traditional partners-and I am thinking here about the transatlantic relations-there is no eternal guarantee of close cooperation with us Europeans..." ${ }^{60}$ Chancellor Merkel may have intended this as a verbal sally at a new US

\footnotetext{
${ }^{59}$ High Representative/Vice-President Federica Mogherini, December 2017. URL: https://eeas.europa.eu/headquarters/headquarters-Homepage/34226/permanent-structured-cooperation-pescofactsheet_en

${ }^{60}$ Yeşilada, Birol, Kuggler, Jacek, Genna, Gaspare and Osman Goktug Tanrikulu. Global Power Transition and the Future of the European Union (London: New York; Routledge. 2018), 57.
} 
administration, but she speaks truth to the notion that Europe was never fooled by an eternal guarantee of cooperation with the US. Maintaining the Western Union despite the North Atlantic Pact showed as much back then and despite Europe's desire to establish strategic autonomy, abandonment fears have always been present in transatlantic relations. ${ }^{61}$ As aforementioned, immediately following WWII Europe worried US isolationism would leave them to manage the threats of its neighbors alone. This anxiety occurred again after the Cold War when Europe was no longer a central focus of American foreign policy, which explains the EU's deliberate steps towards defense integration in the 1990s in an attempt to mitigate security troubles in its own backyard. Incoordination and insufficient resources exposed the shortcomings of European defense capacity and in 1999, the EU established the more comprehensive European Security and Defense Policy. But seventy years of relying on NATO created an "expectation-capacity gap" that puts Europe in the inconvenient position of balancing against what it wants and what it cannot practically achieve, which is why contemporary discourse is exposes the impossible dilemma of being of fear over US withdrawal and the lack willingness on behalf of the EU members to invest in defense.

Despite lip service given to sustaining interoperability with NATO, it is no mystery that European leaders carry doubt over US commitment to the transatlantic partnership after discursive positioning by US President Donald Trump who called NATO obsolete in $2016 .{ }^{62}$ In 2017, European Council President Donald Tusk wrote an open letter to the twenty-seven EU

\footnotetext{
${ }^{61}$ Posen, Barry R. "European Union Security and Defense Policy: Response to Unipolarity?" Security Studies (2006), 15:2, 149-186.

${ }^{62}$ Gore, D'Angelo. “What's Trump's Position on NATO?” FactCheck.org, 11 May 2017. https://www.factcheck.org/2016/05/whats-trumps-position-on-nato/
} 
member leaders to express inter alia concerns over the highly unpredictable declarations of the new American administration that is "seeming to put into question the last 70 years of American foreign policy." The EU has historically been critical of US foreign policy, which is why this is more likely a platform to proclaim a divergence in EU-US values as an aid in combating the existential crisis the EU is experiencing. In that same letter Tusk outlines three major threats Europe faces: an assertive China, an aggressive Russia, and terror and anarchy in the Middle East. ${ }^{63}$ Currently, these threats do not require military response, and if they did, the EU could not mitigate them in the foreseeable future without US assistance. Even as rhetoric, the posturing does have the potential to be a self-fulfilling prophecy for Europe. If the EU pursues an exclusive Europeanist approach to its own security, the US may indeed feel compelled to withdraw especially at a time where isolationist discourse is gaining agency under the US Trump Administration. The US could own up to its own rhetorical grievance of carrying NATO's financial burden and justify a withdrawal under an "America first" policy. This is an improbable outcome, but if it did happen, Europe be left to handle its list of threats alone. This would be challenging for EU leaders because while the European public do occasionally regard the United States a threat to world stability, it paradoxically views Europe's protection as an American job. ${ }^{64}$ A median of 68 percent of NATO member countries surveyed believe that the US would uphold its commitment, more so than

\footnotetext{
${ }^{63}$ Tusk, Donald. “'United we stand, divided we fall”: letter by President Donald Tusk to the 27 EU heads of state or government on the future of the EU before the Malta summit." European Council website, ULR:

http://www.consilium.europa.eu/en/press/press-releases/2017/01/31/tusk-letter-future-europe/

${ }^{64}$ Dombey, Daniel and Stanley Pignal. “European see US as threat to peace." July, 1, 2007. https://www.ft.com/content/70046760-27f0-11dc-80da-000b5df10621
} 
they themselves would be willing to do. ${ }^{65}$ More importantly, Eurobarometer reports in 2017 that of EU member states, $39 \%$ are "somewhat in favor" and only $16 \%$ are "totally in favor" of the creation of an EU army. ${ }^{66}$ The lack of public support in this department is significant because EU governments are generally unwilling to invest in their own defenses, much less in the equipment it would take for the EU to achieve strategic autonomy from NATO.

Independent military capacity would take significant spending that most EU governments are unwilling, and to a certain extent unable to afford. Few European states strictly comply, but NATO members are already obligated to commit $2 \%$ of their GDP to the organization. States barely contribute to NATO, if decision-makers spend the money it would take to compete or replace NATO, they risk losing public support for themselves and the European project. Acquiring heavy lift capabilities to compete with NATO's resources would overstep compliance with this debt and fiscal responsibility that EU institutions expect of EU member states. The Growth and Stability Pact (GSP) stipulates that EU member states are to stay within the $3 \%$ of government deficit and national debt cannot accede $60 \%$ of GDP; increased defense spending would accede such limits. In a clever maneuver, under the 2016 European Defense Action Plan, national capital contributions to the European Defense Fund will be discounted from the expectations of the Growth and Stability Pact. ${ }^{67}$ Individual military spending will still be held within the restrictions

\footnotetext{
${ }^{65}$ Simmons, K., Stokes, Bruce and Jacob Poushter. "NATO Publics Blames Russia for Ukrainian Crisis, but Reluctant to Provide Military Aid." 2015 ULR: http://www.pewglobal.org/2015/06/10/nato-publics-blame-russia-forukrainian-crisis-but-reluctant-to-provide-military-aid/

${ }^{66}$ European Commission. "Designing Europe's Future: Security and Defense." Special Eurobarometer Report 461 (April 2017), 17.

${ }^{67}$ European Commission, "European Defense Action Plan-FAQs" URL: http://europa.eu/rapid/pressrelease_MEMO-16-4101_en.htm
} 
of the GSP. All the same, the resounding critique in contributing to European defense capacity is that it is creates unnecessary duplication of resources that already exist within NATO. To the expectation-capacity gap, Stephanie Anderson argues that Europe's pursuit to build EU military capacity represents a desire, as opposed to a necessity; it is not about defense per say, but about solidifying European identity in the nation-building process, including its desire to play a larger global role. ${ }^{68}$ In semblance to this, the lack of consensus regarding defense integration can be seen both as a crisis of capacity and a crisis of confidence. Not surprisingly, the political ramifications sustain the dilemma. This discussion bleeds inextricably into the discord between the institutional models and their response to the ostensible rise of nationalist politics within the European Union.

\section{Rise in Nationalism}

Donald Tusk's open letter was also provoked by renewed nationalistic discourse as a response to the public dissatisfaction with EU institutions. He sought to warn European leaders that,

...it must be made crystal clear that the disintegration of the European Union will not lead to the restoration of some mythical, full sovereignty of its member states, but to their real and factual dependence on the great superpowers...only together can we be fully independent. ${ }^{69}$

The inescapable conflict is that the independence Tusk seeks is the same type of independence EU member states invoke to maintain autonomy from advanced EU integration. Tusk is speaking

\footnotetext{
${ }^{68}$ Anderson, "Crafting US Security Policy: In Pursuit of a European Identity," 29;129

69 Tusk, Donald. "United we stand, divided we fall": letter by President Donald Tusk" URL: http://www.consilium.europa.eu/en/press/press-releases/2017/01/31/tusk-letter-future-europe/
} 
to the EU's existential crisis that is exacerbated by member states resisting to transfer power in order to increase the efficiency of EU institutions. Because most European states continue to see their militaries as the last bastion of state sovereignty amidst a changing world, participation is not guaranteed. ${ }^{70}$ Interestingly, the appeal is similar to that given by Jean Monnet in the European Coal and Steel Community's High Authority where he deliberated seventy years ago, "If we remain divided as we are, the Europeans will be left exposed to nationalist ambitions and will be forced, as happened in the past, to look for outside guarantees in order to protect themselves against each other. "71 The underlying evidence from then and now, is that when it comes to defense, member states prefer to cooperate case-by-case and not to integrate beyond their ability to maintain agency. The European Defense Community set the precedent of preferred intergovernmentalism, so much so to the point that in a public letter, eleven former generals and admirals counseled EU leaders against the scheme of a supranational army warning, "technocrats playing at arm chair generals, building a fictitious paper army, will only serve to weaken even further our national capabilities...they should beware: paper tigers burn."72 A supranational model may remove the incoordination of asymmetrical capacities and diverging policy interests, and may also be seen as a "coming of age" in the integration process, but it is ultimately lacks supports.

\footnotetext{
${ }^{70}$ Cross. "Security Integration in Europe," 9.

${ }^{71}$ High Authority Doc. 252/55e, op. cit., p. 61 at quoted in Haas, Ernst B. The Uniting of Europe: Political, Social and Economical Forces, 1950-1957. London: Stevens, 1958.

72 "Weakness of a Rapid Reaction Force," Daily Telegraph (London), 12 June 2001, 23 as quoted in Stephanie Anderson. "Crafting US Security Policy: In Pursuit of a European Identity."
} 


\section{Conclusion}

After announcing Europe's protection can no longer be outsourced, European Commission President Jean-Claude Juncker stated a year later at the 2018 Munich Security Conference that "it cannot be that we always have to decide by unanimity when it comes to foreign and defense policies...we would like to emancipate ourselves."73 ${ }^{73}$ the two speeches expose that Juncker is talking of two types of emancipation, the European Commission's emancipation from the limits imposed on them by intergovernmentalism, and freedom from military dependence on the United States. These desires speak to the two questions that underwrite the entirety of the consensus deficit-what model European defense integration should adopt and who should be involved in the process? If contemporary declarations by European leaders are to be taken at face value, perhaps deeper defense integration and an easing on US dependence is on the horizon. But as these treaties demonstrate, disharmony is written in the DNA of European defense integration because nations jealously guard their armies as a kind of incantation of survival. This could change with more time, or with preconditions that incrementally persuade the public towards unification and make it unavoidable for states to integrate their armies, as is consistent with Haas's theory of neofunctionalism. Twenty years later in a Centre virtuel de la connaissance sur l'Europe interview, Mark Eyskens was asked to reflect on his 1991 "worm" reference to which he replied, "as far as military matters go, we are still

\footnotetext{
${ }^{73}$ President Juncker at the Munich Security Conference: EU to become more capable of world politics. January, 20. 2018. https://eeas.europa.eu/headquarters/headquarters-homepage/40100/president-juncker-munich-securityconference-eu-become-more-capable-world-politics_en
} 
completely negligible, that's plain to see. ${ }^{174}$ It is clear that defense integration and time do not move in the same direction. Yet, must be submitted that there is much to be discovered in the unique defense capacity the EU could develop in light of this complex legacy, such as niche capacities and knowledge-based security networks. The EU is an intrinsically unique political project, it stands to reason it would create something unconventional to compete with the circumstances. Still, defense integration may not be able to compete with histories, as Kissinger claims, nor is it an inevitable outcome of European cooperation, as Stephanie Anderson suggests, but French Foreign Minister Robert Marjolin offers a positive, albeit somewhat resigned, picture of post-war reconciliation as an outcome of these early treaties. "Peace reigned in Western Europe...Depending on how one looked at human nature, this state of affairs could be seen either as a triumph of wisdom over blind violence, or as evidence of utter exhaustion." 75 Yet, wisdom is ephemeral and exhaustion unproven to evaporate the preservation of identity. Only by vanquishing the spectre of nationalism could the European Union transcend the quixotic legacy of these three early treaties and achieve European defense integration.

\footnotetext{
${ }^{74}$ Eyskins, Mark. Centre virtuel de la connaissance sur l'Europe URL: https://www.cvce.eu/content/publication/2016/9/20/14f721e6-47e0-4f40-84de692f062b78b7/publishable_en.pdf

${ }^{75}$ Marjolin, Robert. "French Officialdom: Main Obstacle in Rome Treaty Negotiations" as quoted by Sherrill Brown Wells in Pioneers of European integration and Peace, 1945-1963: a Brief History with Documents. (2007) Boston: Bedford/St. Martin's.
} 


\section{Bibliography}

Anderson, Stephanie. 2008. Crafting the EU Security Policy: In pursuit of European Identity. Bolder: Lynne Rienner.

Ardia, Danilo. 1991. "The Byrnes Treaty and the Origins of the Western Alliance, 1946-48." In Twentieth-Century Anglo American Relations, by Jonathan Hollowell, 160-161. London: Longham.

Baylis, John. 1982. "Britain and the Dunkirk Treaty: The Origins of NATO." The Journal of Strategic Studies, June: 247.

Bogdanor, Vernon. 2011. NewStatesman. March 17. Accessed 2018. https://www.newstatesman.com/books/2011/03/bismarck-germany-europe-hitler.

Cini, Michelle, and Nieves Perez-Solórzano Borragàn. 2016. European Union Politics. New York: Oxford University Press.

Commission, European. 2017. Designing Europe's Future: Security and Defense. Special Eurobarometer 461, Eurobarometer .

Coudenhove-Kalergi, Richard. 1923. Pan-Europa.

Cross, Mai'a Davis. 2014. Security Integration in Europe: How Knowledge-based Networks Are Transforming the European Union. Ann Arbor: University of Michigan Press.

D'Angelo. 2017. "What's Trump's Position on NATO?" May 11. https://www.factcheck.org/2016/05/whats-trumps-positions-on-nato/.

Declaration, The Schuman. 1950. May 9. https://europa.eu/european-union/abouteu/symbols/europe-day/schuman-declaration_en.

Dombey, Daniel, and Stanley Pignal. 2007. European see US as threat to peace. July 1. https://www.ft.com/content/70046760-27f0-11dc-80da-000b5f10621.

Dwan, R. 2001. "Jean Monnet and the European Defense Community, 1950-1954." Cold War History.

Eurobarometer. 2017. "Designing Europe's Future: Security and Defense." Special Eurobarameter Report 461.

Eyskins, Mark. 2010. "Centre virtuel de la connaissance sur l'Europe." Centre virtuel de la connaissance sur l'Europe URL: https://www.cvce.eu/content/publication/2016/9/20/14f721e6-47e0-4f40-84de692f062b78b7/publishable_en.pdf. 
Fogarty, Michael P. 1957. "Britain and Europe Since 1945." The Review of Politics, Jan: 90-105.

Forlenza, Rosario. 2017. "The Politics of the Abendland: Christian Democracy and the Idea of Europe after the Second World War." Contemporary European History, 261-286.

Gavin, Victor. 2010. "Were the interest really parallel? The United States, Western Europe and the Early Integration Project." Journal of Transatlantic Studies, 32-43.

Germond, Basil, Jussi M Hanhimaki, and George-Henri Soutou. 2010. The Routledge Handbook of Transatlantic Security. London: Routledge.

Greenwood, Sean. 1984. "Ernest Bevin, France and 'Western Union': August 1945-February 1946." European History Quarterly, July: 319.

—. 1983. "Return to Dunkirk: The Origins of the Anglo-French Treaty of March 1947." The Journal of Strategic Studies, December: 52.

Gualle, Charles De. 1964. "Major Addresses, Statements, and Press Conferences of General Charles de Gualle, May 19, 1958-January 31,1961." New York: French Embassy Press and Information Bureau.

Haas, Enrst B. 1958. The Uniting of Europe: Political, Social and Economical Forces, 19501957. London: Stevens.

Habermas, J., and J Derrida. 2003. "What Binds Europeans Together: A Plea for a Common Foreign Policy, Beginning in the Core of Europe." Constellations, 291-297.

Hollowell, Jonathan. 2001. Twentieth-century Anglo-American Relations. Basingstoke: Palgrave.

Howorth, Jolyon. 2017. "EU-NATO coopertion: the Key to Europe's Security Future." European Security, 456.

Insall, Tony, and P Salomon. 2015. "The Brussels and North Atlantic Treaties, 1947-1949." Documents on British Policy Overseas.

Jones, Seth. 2010. "The European Union and the Security Dilemma." Securities Studies 119.

Junker, Jean-Claude. 2017. "European Commission." June. http://europa.eu/rapid/pressrelease_SPEECH-17-1581_en.htm.

Kissinger, Henry A. 1957. A World Restored: Castlereagh, Metternich and the Restoration of Peace, 1812-1822. Boston: Houghton Mifflin Company.

Larive, Maxime H. A. 2014. Debating European Security and Defense Policy. London: New Yorl: Routlegde. 
Laughland, John. 1998. The Tainted Source: The Undemocratic Origins of the European Ideas. London: Warner Books.

Ludlow, Piers. 1999. "Challenging French Leadership in Europe: Germany, Italy, the Netherlands and the Outbreak of the Empty Chair Crisis of 1965-1966." Contemporary European History 234.

McCormick, John. 2007. The European Superpower. Basingstoke: Palgrave Macmillan.

-. 2005. Understanding the European Union: A Concise Introduction. Bakingstroke: Palgrave Macmillan.

Mogherini, Federica. 2017. PESCO. https://eeas.europa.eu/headquarters/headquartersHomepage/34226/permanent-structured-cooperation-pesco-factsheet_en.

Monnet, Jean. 1978. Memoirs. New York: Doubleday.

Moravcsik, Andrew. 1998. The Choice for Europe: Social Purpose and State Power from Messina to Maastricht. Cornell Studies in Political Economy. Ithaca: Cornell University Press.

Moravcsik, Andrew. 2017. "The Future of Europe: Coping with Crisis ." Great Decisions: Foreign Policy Association.

Nelsen, Brent F., and Alexander Stubb. 1994. The European Union: Readings on the Theory and Practice of European Integration. Bolder: Lynne Rienner.

Nugent, Neill. 2017. The Government and Politics of the European Union. London: Palgrave Macmillion.

Pertinax, By. 1948. "Byrnes Arms Pact Reported Dropped." New York Times, Feb 21.

Posen, Barry. 2006. "European Union Security and Defense Policy: Response to Unipolarity?" Security Studies, 149-186.

Reykers, Yf. 2017. "EU Battlegroups: High costs, no benefits." Contemporary Security Policy, 457-470.

Reynold, D. 1991. Britannia Overruled: British Policy and World Power in the Twentieth Cencury. London: Longham.

Salmon, Trevor, and William Nicoll. 1997. Building European Union: A Documentary History and Analysis. Manchester: Manchester University Press.

Satterthwaite, Joseph C. 1972. "The Truman Doctrine: Turkey." The Annals of American Academy of Political and Social Science. 
Schwartz, Thomas. 1995. The Transnational Partnership: Jean Monnet and Jack McCoy. Washington, DC: Jean Monnet Council.

Spinelli, Altiero, and Ernesto Rossi. 1944. "Manifesto di Ventonene: For a Free and United Europe."

Stokes, K. Simmons, Jocob Poushter, and Jacob Poushter. 2015. NATO Publics Blames Russia for Ukrainian Crisis, but Reluctant to Provide Military Aid. http://www.pewglobal.org/2015/06/10/nato-publics-blame-russia-for-ukrainian-crisisbut-reluctant-to-provide-military-aid/.

Svik, Peter. 2016. "The Czechoslovak Factor in Western Alliance Building, 1945-1948." Journal of Cold War Studies, 137.

Treaty, The Dunkirk. 1947. "Treaty of Alliance and Mutual Between His Majesty in Respect of the United Kingdom of Great Britain and Northern Ireland and the President of the French Republic." The international Law Quarterly.

Tusk, Donald. n.d. "United we stand, divided we fall: letter by President Donald Tusk to the 27 Eu heads of government on the future of the EU before the Malta summit." European Council. http://www.consilium.europa.eu/en/press/press-releases/2017/01/31/tusk-letterfuture-europe/.

Warren, Lansing. 1950. "West Union Speeds Arms Integration: Britain, France, Benelux Meet to Merge Defense Plans into North Atlantic Accord." The New York Times.

Wells, Sherrill Brown. 2011. Jean Monnet: Unconventional Statesman. Boulder: Lynne Rienner. -. 2007. Pioneers of European Integration and Peace, 1945-1963: a Brief History with Document. New York: Bedford St. Martin's.

Whitney, Craig. 1991. "https://www.nytimes.com/1991/01/25/world/war-in-the-gulf-europegulf-fighting-shatters-europeans-fragile-unity.html." War in the Gulf: Europe; Gulf Sighting Shatters Europeans' Fragile Unity.

Yeşilada, Birol, Genna Jacek, Gaspare Osman, and Goktug Tanrikulu. 2018. Global Power Transistion and the Future of the European Union. London: New York: Routledge.

Zeeman, Bert. 1986. "'Britain and the Cold War: An Alternative Approach. The Treaty of Dunkirk Example." European History Quarterly, 353. 